$\underline{\xi}=-m$

\title{
Health impact of toxic metals in facial cosmetics used in Calabar, Nigeria
}

\author{
Julius UkoNaku ${ }^{1 *}$, Bassey E. Inah², Dominic A. Mowang ${ }^{3}$, Terngu P. Ugosor ${ }^{4}$ \\ ${ }^{1}$ Department of General Studies, College of Health Technology, Calabar \\ ${ }^{2}$ Department of Chemistry University of Calabar \\ ${ }^{3}$ Department of Environmental Biology, University of Calabar \\ ${ }^{4}$ College of Education Katsina-Ala \\ *Corresponding author E-mail:nakujul@yahoo.com
}

\begin{abstract}
The present study highlights the health risk factor of heavy metals in cosmetics considering their habitual use in the society today. This safety assessment has become inevitable because of the high demand for these products which has resulted to flooding the markets with low quality cosmetics. Digestion was by $20 \mathrm{~mL}$ mixture of nitric acid $\left(\mathrm{HNO}_{3}\right)$ and hydrogen peroxide $\left(\mathrm{H}_{2} \mathrm{O}_{2}\right)$ in the ratio of 3:1 and was heated in a hot plate for $2-3$ hours at $90{ }^{\circ} \mathrm{C}$. The choice of this mixture was informed by literature to yield the highest amounts in metal digestion. The mean metal concentrations of these products are; $1.2758,0.9599,0.1262,0.0504$ and $0.0068 \mathrm{mg} / \mathrm{kg}$ while the ranges are: $0.140-5.823,0.054-3.908,0.021-0.820,0.028-0.071$ and $0.001-0.236 \mathrm{mg} / \mathrm{kg}$ respectively for $\mathrm{Mn}, \mathrm{Ni}, \mathrm{Cr}, \mathrm{Cd}$ and $\mathrm{Pb}$. From the analysis, $40 \%, 74.28 \%$, and $17.14 \%$ of the products has $\mathrm{Cd}$, $\mathrm{Ni}$ and $\mathrm{Mn}$ respectively exceeded the standard. $\mathrm{Pb}$ was not detected in majority of the products. Though cosmetic safety cannot be ascertained only by their heavy metal content, the present paper focuses solely on the contribution of heavy metals as a risk factor to the consumption of these products.
\end{abstract}

Keywords:Concentration; Contamination; Cosmetics; Percutaneous Absorption; Toxic.

\section{Introduction}

The daily use of cosmetics has increased geometrically due to increase in the population group with a high quest for these products. In the past, the elderly were not quite involved in this aesthetics but today every subgroup of the population seem to be actively involved. The market therefore, has been flooded with varieties of these cosmetic products some of which are manufactured under unsafe conditions. Cosmetics are preparations that are applied to the body to improve its attractiveness (Encarta, 2009). Facial cosmetics commonly used include lipsticks, lip glosses, face cleansers, face powders, eye shadows, shaving powders, eye pencils, kohl and kajal. The face has been chosen for this study because it carries the largest proportion of the daily loads of cosmetics

Research has shown that many of these heavy metals are from the raw materials used as ingredients and manufacturing activities (Sahu et al. 2014).Though many of the users of these products are unaware of the dangers, the facts still remains that the use of these products can cause complications in the health status of the users (Aldeyel. et al. 2018, Orisakwe et al. 2013, Sahu et al. 2014). These health issues are of great public concern and have triggered research in various dimensions. The campaign for safe cosmetics (2007) reported that $61 \%$ of 33 popular brands of lipsticks tested contain lead at levels up to $0.65 \mathrm{ppm}$. Bellinger, (2008) has shown that even low levels of lead is a cause for concern particularly in pregnant women and developing infants

Liu et al. (2013) in their research in California showed that 32 of the lip products tested contain high concentration of aluminium and titanium. All the products tested positive for manganese while $75 \%$ tested positive for lead and $47 \%$ of the samples had lead concentrations above that recommended by US FDA in candy likely to be consumed by children. Chromium and nickel were also found in almost all the samples with concentrations of 9.72 and 9.73 ppm respectively.

\subsection{Percutaneous absorption of cosmetics}

A study published on percutaneous absorption of lead oxide by Larese et al. (2006) showed that lead can passed through intact human skin with a median amount at 24 hours of $2.9 \mathrm{ng} / \mathrm{cm}^{3}$. They stated that washing may enhance skin uptake by penetrating-enhancing effects of surfactants like sodium lauryl sulphate. The penetration increases when used on broken skin for both lead and other metals (Hostynet et al. 2003)

Low skin $\mathrm{pH}$ which favours the ionization of metals, hydration of skin enhanced by tropical temperature, moisturizing nature of some lotions, and occlusion of skin all facilitate penetration of organic compounds (Zhai et al. 2001). Loading concentration (amount of cosmetics per unit area of skin) and total time of exposure of the skin to cosmetics per day has a direct relationship with the degree of penetration. The higher the loading concentrations and time of cosmetic on the skin, the higher the rate of absorption (Larese et al. 2006, Dykeman et al. 2002). Larese et al. also asserted that based on experiment and assumptions made, the contribution of dermal lead uptake 
to blood lead was substantial. This is in agreement with Aldeyel et al. (2018) who reported a blood lead level as high as $39 \mathrm{mg} / \mathrm{dl}$ in infants due to use of kohl. Shaltout et al. (1981) reported a case of lead encephalopathy in 20 patients aged 1 - 18 months in Kuwait with blood lead ranging from $60-257 \mathrm{mg} / \mathrm{dl}$. Two of the patients died before treatment, three died during the treatment, and four of those who survived had different neurological problems and the source of lead was confirmed to be kohl. Kajal and traditional digestive remedies have also been known to contain high levels of lead (Aldeyel et al. 2018).

\subsection{Health implications of heavy metals in cosmetics}

A report by science linking environmental contaminants exposure with fertility and reproductive health impacts in adult female (2008), revealed that heavy metals play a substantial role in complications associated delayed puberty, breast development, ovarian dysfunction, etc. In relation to puberty outcomes, Selevan et al. (2003); Wu et al. (2003), reported delayed menarche, delayed breast, delayed pubic hair as a result of serum lead. In a similar studies, Yang et al. (2002) and Tang \& Zhu (2003), reported increased in odds of polymenorrhea, hypermenorrhea and dysmenorrhea in females in lead battery plant and mercury battery plant workers. Increased difficulty in becoming pregnant, infertility, and follicle dysfunction have also been associated with heavy metals in blood (Wu et al. 2003).

A study in India on adverse reproductive and child health outcomes among people living near highly toxic waste water drains in Punjab, (2009), reported that although no direct relationship was established, heavy metals and pesticides exposure may be potential risk factors for adverse reproductive and child health outcomes. Numerous studies have linked the role of heavy metals to occurrence of impaired reproductive outcomes of males (Telisman et al. 2000, Eibensoteine et al. 2005), spontaneous abortion, (Rowland et al. 1994), preterm delivery (Fagher et al. 1993; Saxena et al. 1994, low birth weight and abnormal pregnancy (Itai et al. 2004, Ahmad et al. 2001).

Lead has been implicated to shift the sex ratio to few boys born to, and may be related to low testosterone at the time of conception (James 2006). Also, Dickson and Parker (1994) reported that professional drivers always exposed to petroleum products are likely to have fewer sons than girls.

Heavy metals are also known endocrine disruptors. A study on arsenic as an endocrine-disrupting chemical in reproductive systems reports that adult rats that consumed drinking water with arsenite at $5 \mathrm{mg} / \mathrm{kg}$ of body weight per day 6 days a week for four weeks have reproductive track abnormalities such as suppression of gonadotrophins and testicular androgen and germ cell degeneration. All symptoms similar to those induced by estrogen agonist (Jana et al. 2006). Waalkes et al. (2000), equally reported that mice injected with sodium arsenate at $0.5 \mathrm{mg} / \mathrm{kg}$ once a week for 20 weeks, males had testicular interstitial cell hyperplasia and tubular degeneration that probably resulted from the interstitial cell hyperplasia.

Again, Tseng (2005) and Livingstone et al. (2002), have reported that the Blackfoot disease which is associated with drinking arsenic contaminated water, is endemic in southwest Taiwan and also associated with type 2 diabetes. The type 2 diabetes compromises fertility thus, making arsenic a potential endocrine-disrupting chemical on both diabetes and reproductive system.

Cadmium has also been reported as a heavy metal regarding its biological activities and as an endocrine-disrupting chemical (Henson \& Chedrese, 2004). Maternal exposure to high levels of cadmium has led to high level of preterm delivery (Nishijo et al. 2002). Cadmium at high concentrations inhibits placental progesterone synthesis and expression of low density lipoprotein receptor that is needed to bring cholesterol substrate into cells (Jolibois et al. 1999; Jolibois et al. 1999).

Chromium in the trivalent state has been known to be an essential nutrient required for normal energy metabolism but $\mathrm{Cr}^{6+}$ is known to be toxic. Agency for Toxic Substances and Disease Registry (ATSDR, 2014) ranks $\mathrm{Cr}^{6+} 17$ in its National Priority List (NPL) of Hazardous Substances. The relationship between $\mathrm{Cr}^{3+}$ and $\mathrm{Cr}^{6+}$ depends on $\mathrm{pH}$ and oxidative properties of the environment with $\mathrm{Cr}^{3+}$ dominating because of its stability (Liu et al. 2013). The toxicological profile for Chromium as reported by Agency for Toxic Substances \& Disease Registry (ATSDR, 2012), showed that the toxicity of Chromium depends on its valency and nature of ligands. The toxicity is mainly caused by $\mathrm{Cr}^{6+}$ because of higher cellular uptake of $\mathrm{Cr}^{6+}$ than $\mathrm{Cr}^{3+}$. They reported that this is because chromate anion $(\mathrm{CrO} 4)^{2-}$ can enter the cells via facilitated diffusion through non-specific anion channels (similar to phosphate and sulphate anions). Absorption of $\mathrm{Cr}^{3+}$ is via passive diffusion and phagocytosis. By intracellular reduction, hexavalent chromium is reduced by reducing agents such as glutathione to Chromium (III) which is stable. The international Agency for Research on Cancer (IARC, 2012), has classified Chromium as genotoxic i.e, its capable of damage to the DNA even in its reduced form.

The objective of this present study is to highlight the presence of heavy metals (cadmium, lead, nickel, chromium and manganese) in facial cosmetics that have dominated our markets and are indiscriminately and habitually used. It also raises concern on the potential health risks associated with the consumption of these products.

\section{Materials and methods}

Analytical grade chemicals were used to prepare standard solutions and reagents. All glassware and plastics were washed with deionized water, rinsed with $\mathrm{HNO}_{3}$ and finally with deionized water

\subsection{Sampling}

A group of female students in the Cross River State College of Health Technology, Calabar (age between 18 - 35 years) were requested to write the facial cosmetics they have used in the past and the ones they were using the time. These consisted of 9 face powders, 8 eye pencils, 6 lip glosses, 5 face cleansers and 7 lip sticks. The list was then used to purchase the items in the popular Watt and Marian markets. The items making a total of 35 products are presented in Table 1.

Table 1:A Description of Different Facial Cosmetics Used. NA= Not Applicable

\begin{tabular}{|c|c|c|c|c|c|c|c|c|}
\hline $\mathrm{S} / \mathrm{N}$ & $\begin{array}{l}\text { Sample } \\
\text { ID }\end{array}$ & Batch No & Colour & Brand Name & Manufacturer & $\begin{array}{l}\text { Expiry } \\
\text { Date }\end{array}$ & Product Description & Nature/State \\
\hline & \multicolumn{8}{|c|}{ FACE CLEANSERS } \\
\hline 1 & FC 01 & 250PA1418 & Yellowish & babyface & $\begin{array}{l}\text { RDL pharmaceutical lab. } \\
\text { Philippines. dist. In Nig. By } \\
\text { Topaz cosmetics limited }\end{array}$ & $10 / 02 / 2021$ & $\begin{array}{l}\text { Papaya extract for beau- } \\
\text { tiful and younger look- } \\
\text { ing skin }\end{array}$ & liquid \\
\hline 2 & FC 02 & NA & Colourless & maxi-peel & $\begin{array}{l}\text { Manufactured in the Philip- } \\
\text { pines by splash }\end{array}$ & NA & $\begin{array}{l}\text { Deep cleansing, anti- } \\
\text { aging and smoothening }\end{array}$ & liquid \\
\hline 3 & FC 03 & NA & Colourless & clean \& clear & Johnson \& Johnson consumer & 2019 & Deep cleaning astrin- & liquid \\
\hline
\end{tabular}




\begin{tabular}{|c|c|c|c|c|c|c|c|c|}
\hline & & & & & product companies, Canada & & $\begin{array}{l}\text { gent salicylic acid acne } \\
\text { modification }\end{array}$ & \\
\hline 4 & $\mathrm{FC} 04$ & NA & Yellowish & Sequence & $\begin{array}{l}\text { Cybele cosmetics Ltd, } 100 \\
\text { Lapido street matari industrial } \\
\text { estate, Lagos Nigeria. }\end{array}$ & NA & $\begin{array}{l}\text { Facial cleanser for } \\
\text { everyday use }\end{array}$ & liquid \\
\hline \multirow[t]{2}{*}{5} & FC 05 & 0001 & Yellowish & Carrot xtract & $\begin{array}{l}\text { Made in EU marketed by } \\
\text { MMF Ltd }\end{array}$ & $06 / 21$ & Super facial cleanser & liquid \\
\hline & \multicolumn{4}{|c|}{ EYE PENCILS } & & & & \\
\hline 6 & EP 01 & 001 & BLACK & Airemain & Airemain Pen Industry CO.Ltd & NA & $\begin{array}{l}\text { Eye liner and lip liner } \\
\text { pencil with vit. A \& E }\end{array}$ & Soft solid \\
\hline 7 & EP 02 & 018 & $\begin{array}{l}\text { Dark- } \\
\text { brown }\end{array}$ & Iman make up & NA & NA & $\begin{array}{l}\text { Fashion best colour, } \\
\text { water proof make up } \\
\text { with vit. A \& E }\end{array}$ & Soft solid \\
\hline 8 & EP 03 & 018 & $\begin{array}{l}\text { Light } \\
\text { brown }\end{array}$ & Davis & NA & NA & $\begin{array}{l}\text { Eye liner and lip liner } \\
\text { pencil with vit. A \& E } \\
\text { Extra water proof pro- } \\
\text { tective }\end{array}$ & Soft solid \\
\hline 9 & ЕР 04 & NA & Black & $\begin{array}{l}\text { Beauty Abso- } \\
\text { lute }\end{array}$ & NA & NA & Eye liner pencil & Soft solid \\
\hline 10 & ЕР 05 & MAC 1599 & Black & M.A.C & NA & NA & $\begin{array}{l}\text { Eye/lip liner pencil } \\
\text { Aloe vera \& vit E }\end{array}$ & Soft solid \\
\hline 11 & ЕР 06 & 029 & Dark-blue & Airemain & Airemain pen industry Co. Ltd & NA & $\begin{array}{l}\text { Eye liner and lip liner } \\
\text { pencil with vit. E Extra } \\
\text { water proof protection }\end{array}$ & Soft solid \\
\hline 12 & ЕР 07 & & Black & $\begin{array}{l}\text { Precision tip } \\
\text { eye liner }\end{array}$ & NA & NA & Eye liner water proof & Soft solid \\
\hline \multirow[t]{2}{*}{13} & ЕР 08 & 001 & Black & MAF & Made in P.R .P & 2020 & $\begin{array}{l}\text { Water proof and long } \\
\text { lasting }\end{array}$ & Soft solid \\
\hline & \multicolumn{3}{|c|}{ FACE POWDERS } & & & & & \\
\hline 14 & FP 01 & 00205 & Brown & Iman make up & $\begin{array}{l}\text { Iman cosmetics New York. } \\
\text { Made in USA }\end{array}$ & NA & Luxury pressed powder & powder \\
\hline 15 & FP 02 & 8157 & Brown & Green Tea & Made in China & NA & $\begin{array}{l}\text { Repairing powder cake; } \\
\text { silky fresh touch }\end{array}$ & powder \\
\hline 16 & FP 03 & 00205 & Brown & Black up & NA & NA & $\begin{array}{l}\text { Pressed powder, trans- } \\
\text { lucent }\end{array}$ & powder \\
\hline 17 & FP 04 & NA & Brown & $\begin{array}{l}\text { Sleek make } \\
\text { up }\end{array}$ & $\begin{array}{l}\text { Sleek cosmetics New York; } \\
\text { NY10022. Made in USA }\end{array}$ & NA & $\begin{array}{l}\text { Pressed powder; trans- } \\
\text { lucent }\end{array}$ & powder \\
\hline 18 & FP 05 & 20170407 & Brown & Jose face & Formulated by Didosh & $06 / 04 / 2021$ & $\begin{array}{l}\text { Flawless finish pressed } \\
\text { SPF-8 sunscreen tone } 1\end{array}$ & powder \\
\hline 19 & FP 06 & NA & $\begin{array}{l}\text { Dark- } \\
\text { brown }\end{array}$ & Miss Didosh & NA & $01 / 10 / 2015$ & $\begin{array}{l}\text { Finish crème powder. } \\
\text { SPF-B sunscreen skin } \\
\text { tone } 3\end{array}$ & powder \\
\hline 20 & FP 07 & $8807-5$ & Brown & $\begin{array}{l}\text { Top country } \\
\text { make up }\end{array}$ & NA & $26 / 09 / 2018$ & $\begin{array}{l}\text { Didosh lasting whiten- } \\
\text { ing }\end{array}$ & powder \\
\hline 21 & FP 08 & NA & Brown & $\begin{array}{l}\text { Sleek make } \\
\text { up liquid } \\
\text { foundation }\end{array}$ & Made in P.R.C & NA & $\begin{array}{l}\text { Semi-solid foundation } \\
\text { make up }\end{array}$ & Semi-solid \\
\hline \multirow[t]{2}{*}{22} & FP 09 & $815 \mathrm{~L}$ & Brown & $\begin{array}{l}\text { Aisha POP } \\
\text { best }\end{array}$ & NA & NA & Best POP & Powder \\
\hline & \multicolumn{2}{|c|}{ LIP GLOSS } & & & & & & \\
\hline 23 & LG 01 & NA & Colourless & Beauty Matte & NA & NA & Long lasting Lip gloss & Jelly-like \\
\hline 24 & LG 02 & NA & $\begin{array}{l}\text { Light blue } \\
\text { with shiny } \\
\text { particles }\end{array}$ & $\begin{array}{l}\text { Romantic } \\
\text { May }\end{array}$ & NA & 2020 & Brilliant lip gloss & Thick liquid \\
\hline 25 & LG 03 & NA & Colourless & Absolute & NA & NA & Long lasting lip gloss & Thick liquid \\
\hline 26 & LG 04 & NA & Red & Classic Queen & $\mathrm{NA}$ & NA & Matte lip gloss & Semi-solid \\
\hline 27 & LG 05 & NA & $\begin{array}{l}\text { Light- } \\
\text { brown }\end{array}$ & Golden Rose & $\begin{array}{l}\text { Made in P.R.C Dist. By gold- } \\
\text { en Rose industry Ltd }\end{array}$ & NA & $\begin{array}{l}\text { Lovely shining squeez- } \\
\text { ing-in-shine super shiny } \\
\text { tasty lip gloss }\end{array}$ & Semi-solid \\
\hline 28 & \multicolumn{2}{|c|}{ LIPSTICK } & Ox-blood & Miss Lovely & NA & NA & Long lasting lip gloss & Semi-solid \\
\hline 29 & LS 01 & NA & Dark-red & $\begin{array}{l}\text { Milanni } \\
\text { Beauty Matte }\end{array}$ & NA & NA & 24 H Lip stick & Soft solid \\
\hline 30 & LS 02 & NA & Brown & $\begin{array}{l}\text { Milanni (MB) } \\
\text { Beauty }\end{array}$ & NA & NA & 24 H Lip stick & Soft solid \\
\hline 31 & LS 03 & NA & Pink & M.A.C.C & NA & NA & Matte 24 H lip stick & Soft solid \\
\hline 32 & LS 04 & NA & $\begin{array}{l}\text { Light- } \\
\text { brown }\end{array}$ & Island Honey & NA & NA & NA & Soft solid \\
\hline 33 & LS 05 & NA & $\begin{array}{l}\text { Light- } \\
\text { green }\end{array}$ & $\begin{array}{l}\text { Romantic } \\
\text { May }\end{array}$ & NA & NA & NA & Soft solid \\
\hline 34 & LS 06 & NA & Orange & Jackelin & NA & NA & $\begin{array}{l}24 \text { Hrs long lasting lip } \\
\text { stick }\end{array}$ & Soft solid \\
\hline 35 & LS 07 & NA & Black & Mascara & NA & NA & NA & liquid \\
\hline
\end{tabular}

\subsection{Sample preparation}

Digestion was by a mixture of nitric acid and hydrogen peroxide in the ratio of 3:1.1.0 g of each sample was measured and deposited in a beaker previously washed with distilled deionized water. Then, $20 \mathrm{~mL}$ of the acid mixture was added and heated on a hot plate to $90{ }^{\circ} \mathrm{C}$ for 2-3 hours until white fumes appear and close to dryness. $10 \mathrm{~mL}$ of the acid mixture was again added and heated until digestion was 
complete. Distilled deionized water was then added and filtered with a whatmann filter paper into a $100 \mathrm{~mL}$ calibrated flask and made to the mark. The digest was analyzed by AAS (Agilent Technologies 200 series AA) for Cd (228.8 nm), $\mathrm{Cr}(357.90 \mathrm{~nm}), \mathrm{Mn}(279.5 \mathrm{~nm}), \mathrm{Ni}$ $(232.0 \mathrm{~nm})$, and $\mathrm{Pb}(217.0 \mathrm{~nm})$. Prior to analysis, standard metal solutions were used to calibrate the AAS machine. The instrument settings and operational conditions were done in accordance with the manufacturer's specifications.

\subsection{Statistical treatment of data}

In all cases, measurements were performed in triplicate. One-sample t-tests were used to test the significance of differences within individual treatments; while analysis of variance (ANOVA) was used to test differences for all investigated variables during the experiment between treatments at the $5 \%$ probability level $(\mathrm{p} \leq 0.05)$ by means of the SPSS 17.0 (SPSS, Chicago, Ill.) statistical package.

\section{Results and discussions}

The summary of results is presented in Table 2. Researchers tested 35 cosmetic products in total as pointed out in 2.1. The results show that $90 \%$ of the products contain each of the heavy metals except $\mathrm{Pb}$. A general overview of the result does not seem to raise much public health concern but toxic heavy metals are a matter of concern even at low concentrations (Wang et al. 2002, Miranda et al. 2007). The mean values show that $\mathrm{Mn}$ has the highest concentration of 1.2758, then $\mathrm{Ni}(0.9599), \mathrm{Cr}(0.1262), \mathrm{Cd}(0.0504)$ and $\mathrm{Pb}$ with smallest concentration of $0.0068 \mathrm{mg} / \mathrm{kg}$ respectively. Pb was detected in only two samples, miss lovely lip gloss and milanni (MB) beauty lipstick. Cadmium has been reported to cause impairment in male and female fertility (Chia et al. 1994; Al-Bader et al. 1999). In this present study, Cd was detected in $100 \%$ of the samples but in low concentrations. It has the lowest and highest values of $0.028 \mathrm{and} 0.071 \mathrm{mg} / \mathrm{kg}$ with a mean concentration of $0.0504 \mathrm{mg} / \mathrm{kg}$. Table 3 illustrates the mean concentration values of metals in each group of cosmetics. It shows that lipsticks have the highest mean Cd concentration of $0.0681 \mathrm{mg} / \mathrm{kg}$ and Face Powders with the lowest concentration of $0.0398 \mathrm{mg} / \mathrm{kg}$. In general mean Cd concentrations in different cosmetic groups appear in the order Lipsticks $(0.0681 \mathrm{mg} / \mathrm{kg})>\mathrm{lip}$ glosses $(0.0610 \mathrm{mg} / \mathrm{kg})>$ eye pencils $(0.0437 \mathrm{mg} / \mathrm{kg})>$ face cleansers $(0.0424 \mathrm{mg} / \mathrm{kg})>$ face powders $(0.0398 \mathrm{mg} / \mathrm{kg})$. Comparing the individual values with the acceptable standard, as presented in table 4, the results show that the cosmetic products do not quite raise public health risks regarding $\mathrm{Cd}$.

Table 2:Concentration of Heavy Metals in Cosmetics $(\mathrm{mg} / \mathrm{Kg})$

\begin{tabular}{|c|c|c|c|c|c|c|}
\hline \multirow{2}{*}{$\mathrm{S} / \mathrm{N}$} & \multirow{2}{*}{ Sample ID } & \multicolumn{4}{|c|}{ Metal concentration in $\mathrm{mg} / \mathrm{kg}$} & \multirow[b]{2}{*}{$\mathrm{Pb}$} \\
\hline & & $\mathrm{Cd}$ & $\mathrm{Cr}$ & $\mathrm{Mn}$ & $\mathrm{Ni}$ & \\
\hline 1 & FC 01 & 0.035 & ND & ND & 0.054 & ND \\
\hline 2 & FC 02 & 0.042 & ND & ND & ND & ND \\
\hline 4 & $\mathrm{FC} 04$ & 0.042 & ND & ND & ND & ND \\
\hline 5 & FC 05 & 0.047 & ND & ND & 0.445 & ND \\
\hline 6 & EP 01 & 0.044 & 0.056 & 0.723 & 0.578 & ND \\
\hline 7 & EP 02 & 0.050 & 0.550 & 5.019 & 0.679 & ND \\
\hline 8 & EP 03 & 0.049 & ND & ND & 0.065 & ND \\
\hline 9 & EP 04 & 0.051 & ND & ND & 0.754 & ND \\
\hline 10 & EP 05 & 0.045 & 0.600 & 1.089 & 0.483 & ND \\
\hline 11 & EP 06 & 0.042 & 0.070 & ND & ND & ND \\
\hline 12 & EP 07 & 0.041 & 0.087 & ND & 0.765 & ND \\
\hline 13 & EP 08 & 0.028 & 0.062 & 0.448 & 0.078 & ND \\
\hline 14 & FP 01 & 0.037 & 0.070 & ND & 0.762 & ND \\
\hline 15 & FP 02 & 0.040 & 0.064 & ND & 0.054 & ND \\
\hline 16 & FP 03 & 0.031 & 0.611 & ND & 0.514 & ND \\
\hline 18 & FP 05 & 0.031 & ND & ND & 0.621 & ND \\
\hline 19 & FP 06 & 0.029 & 0.031 & 1.474 & 2.397 & ND \\
\hline 20 & FP 07 & 0.040 & 0.052 & 4.886 & 1.446 & ND \\
\hline 21 & FP 08 & 0.047 & 0.352 & 5.823 & 2.543 & ND \\
\hline 22 & FP 09 & 0.064 & 0.055 & 4.556 & 3.908 & ND \\
\hline 23 & LG 01 & 0.055 & 0.055 & 0.784 & 0.842 & ND \\
\hline 24 & LG 02 & 0.057 & 0.063 & 0.345 & 0.427 & ND \\
\hline 25 & LG 03 & 0.061 & 0.053 & 0.694 & 0.654 & ND \\
\hline 26 & LG 04 & 0.061 & 0.071 & 1.774 & 2.642 & ND \\
\hline 27 & LG 05 & 0.061 & 0.450 & 3.886 & 0.335 & ND \\
\hline 28 & LG 06 & 0.071 & 0.820 & 0.491 & 0.074 & 0.001 \\
\hline 29 & LS 01 & 0.069 & 0.076 & 0.432 & 0.782 & ND \\
\hline 30 & LS 02 & 0.061 & 0.031 & 1.013 & 0.397 & 0.236 \\
\hline 31 & LS 03 & 0.070 & 0.054 & 2.443 & 2.630 & ND \\
\hline 32 & LS 04 & 0.066 & 0.021 & 2.335 & 3.052 & ND \\
\hline 33 & LS 05 & 0.070 & 0.064 & 3.441 & 1.329 & ND \\
\hline 34 & LS 06 & 0.070 & ND & 2.331 & 2.872 & ND \\
\hline Range & & $0.028-0.071$ & $0.021-0.820$ & $0.140-5.823$ & 0.054-3.908 & $0.001-0.236$ \\
\hline
\end{tabular}

Legend: FC = Face cleansers; $\mathrm{EP}=$ Eye pencils; FP= Face powders; $\mathrm{LG}=$ Lip gloss; $\mathrm{LS}=$ Lipsticks; ND =Not detected

\begin{tabular}{llllll}
\hline Cosmetics & $\mathrm{Cd}$ & $\mathrm{Cr}$ & $\mathrm{Mn}$ & $\mathrm{Ni}$ & $\mathrm{Pb}$ \\
\hline
\end{tabular}




\begin{tabular}{lllll}
\hline Face Cleansers & 0.0424 & 0.000 & 0.000 & 0.0998 \\
Eye Pencils & 0.0437 & 0.1778 & 0.9098 & 0.4252 \\
Face Powders & 0.0398 & 0.1372 & 1.8754 & 1.4587 \\
Lip Glosses & 0.0610 & 0.2520 & 1.3290 & 0.000 \\
Lip Sticks & 0.0681 & 0.0351 & 1.7890 & 0.8290 \\
\hline
\end{tabular}

Table 4:International Standard Values for Some Toxic Heavy Metals in Cosmetics $(\mathrm{mg} / \mathrm{Kg})$

\begin{tabular}{|c|c|c|c|c|c|c|}
\hline & $\mathrm{Cd}$ & $\mathrm{Cr}$ & $\mathrm{Mn}$ & $\mathrm{Ni}$ & $\mathrm{Pb}$ & Reference \\
\hline Germany & 0.1 & & & & 0.5 & Whitehouse L. (2017) \\
\hline US FDA & & 50 & & & 10 & US FDA (2018) \\
\hline Canada & 3 & & & & 10 & Health Canada (2012) \\
\hline Asian & 5 & & & & 20 & ASEAN Guidelines on cosmetics (2017) \\
\hline WHO* & 2 & & & & 2 & Joint WHO/FAO expert committee (2002) \\
\hline
\end{tabular}

*In food not cosmetics.

In the analysis, $40 \%$ (14) of the total products including all lipsticks and lip glosses marginally exceeded the EU standard for Cd. Sani et al. (2016) reported a range of 0.07-1.74 mg/kg Cd in face powders in Kano while Liu et al. (2013), Nasirudeen\& Amaechi (2015) reported mean and range values of 1.16 and $0.12-1.11 \mathrm{mg} / \mathrm{kg}$ respectively.

Table 5: Adequate Intake (AI) for Manganese and Nickel in $\mathrm{mg} / \mathrm{Kg}$

\begin{tabular}{|c|c|c|c|c|}
\hline Life stage & Age & $\begin{array}{l}\text { Males } \\
(\mathrm{Mn})\end{array}$ & $\begin{array}{l}\text { Female } \\
(\mathrm{Mn})\end{array}$ & $\begin{array}{l}\text { Male/Female } \\
(\mathrm{Ni})\end{array}$ \\
\hline Infants & $0-6$ months & 0.003 & 0.003 & 0.009 \\
\hline Infants & 7-12 months & 0.6 & 0.6 & 0.039 \\
\hline Children & $4-8$ years & 1.5 & 1.5 & 0.099 \\
\hline Children & $9-13$ years & 1.9 & 1.6 & 0.128 \\
\hline Adolescents & 14-18 years & 2.2 & 1.6 & 0.137 \\
\hline Adults & 19 years and older & 2.3 & 1.8 & 0.162 \\
\hline Lactation & All ages & & 2.6 & \\
\hline
\end{tabular}

For Cr, $31.42 \%$ (11) including all face powders were devoid of it. From table 2, a mean value of 0.1262 and range of $0.021-0.820 \mathrm{mg} / \mathrm{kg}$ were detected. A search through the different regulatory bodies showed only US FDA with a value of $50 \mathrm{mg} / \mathrm{kg}$ which is much beyond our values. From the different cosmetic groups, the descending order of $\mathrm{Cr}$ is lip glosses $(0.252 \mathrm{mg} / \mathrm{kg})>$ eye pencils $(0.1778 \mathrm{mg} / \mathrm{kg})>$ face powders $(0.1372 \mathrm{mg} / \mathrm{kg})>$ lipsticks $(0.0351 \mathrm{mg} / \mathrm{kg})>$ face cleansers with no detected value. In a similar study, Sahu et al. (2014) reported that $\mathrm{Cr}$ was detected in 50\% (15 of 30) of the samples with a range of 0.45-17.83 ppm. Also, Ackah et al. (2015) and Ullah et al. (2017) reported a mean $\mathrm{Cr}$ concentration in cosmetics to be 0.90 and $0.074 \mp 0.002 \mathrm{mg} / \mathrm{kg}$ respectively. Our result is in substantial agreement with Sahu et al. (2014), Ackah et al. (2015) and Ullah et al. (2017) which all fall below the bench mark of $50 \mathrm{mg} / \mathrm{kg}$ as stipulated by US FDA.

As an essential nutrient, several enzyme systems have been reported to interact or depend on Mn for their catalytic or regulatory functions. As such, it is required for the formation of healthy cartilage, bones and the urea cycle (ATSDR, 2012). It also aid in the maintenance of the mitochondria, production of glucose and wound healing (ATSDR, 2012). Although Mn is useful nutritionally, excess exposure can result to neurological disorder known as manganism which is characterized by tremors, difficulty in walking, facial muscle spasm and aggressiveness (ATSDR, 2014). A search through the various regulatory bodies does not contain the standard values for Mn as indicated in table 4. The Adequate Intake (AI) values were used instead. In our result of analysis, Mn recorded the highest value of $5.823 \mathrm{mg} / \mathrm{kg}$ with a $62.85 \%$ detection. In fact, Mn content analyzed in sleek make up liquid foundation $(5.823 \mathrm{mg} / \mathrm{kg}) \mathrm{exceeds}$ the amount of $\mathrm{Cd}(1.764 \mathrm{mg} / \mathrm{kg})$ in all the products put together. This value of $\mathrm{Mn}(5.823 \mathrm{mg} / \mathrm{kg})$ is higher than adequate daily intake (AI) even for lactation mothers (table 5). Regarding each of the cosmetic groups, the values for Mn still appear highest except for face cleansers where it was not detected.

Nickel was detected in $88.57 \%$ (31 of 35) with a mean concentration and range of 0.9599 and $0.054-3.908 \mathrm{mg} / \mathrm{kg}$ respectively. The highest value of $3.908 \mathrm{mg} / \mathrm{kg}$ was detected in face powder, Aisha POP best. These high values of Ni are notable causes of allergic and contact dermatitis (IARC 2012, ATSDR 2014). Both cancerous and noncancerous respiratory effects have been observed in human and animals exposed to air bone Ni compounds. Chronic bronchitis, emphysema, pulmonary fibrosis and impaired lung function have been observed in Ni welders and foundry (Sainic et al. 2001, Sahu et al. 2014). From table 2 and 5, $74.28 \%$ (26 of 35) exceeded the acceptable daily intake (AI) threshold for in adults. 


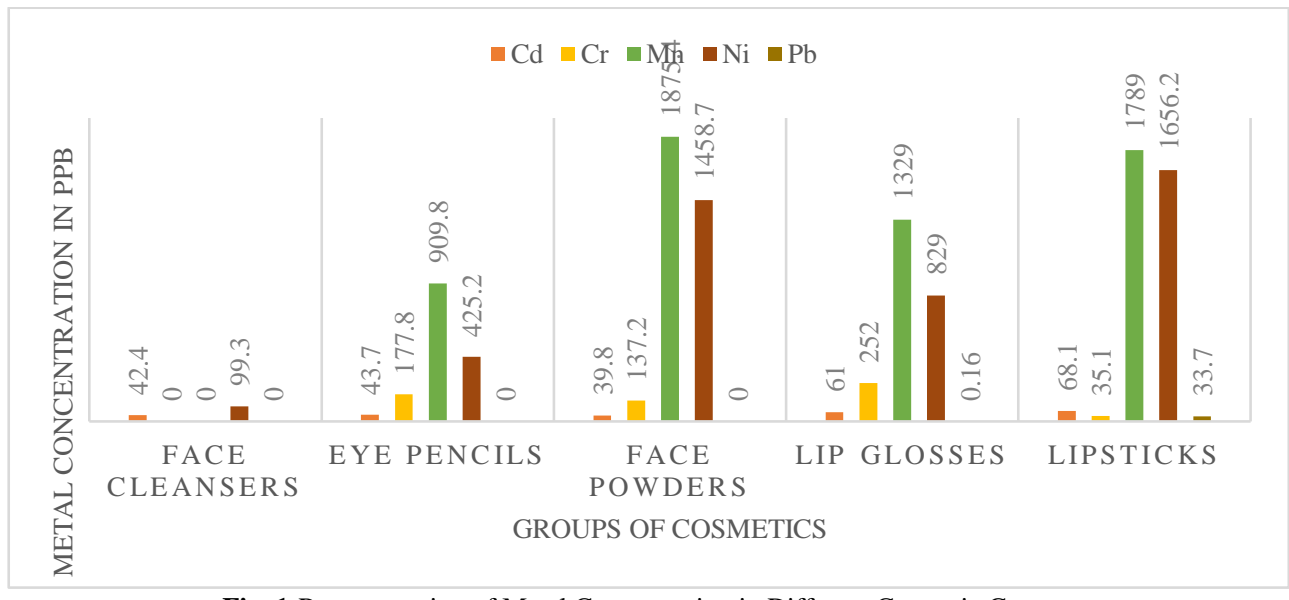

Fig. 1:Representation of Metal Concentration in Different Cosmetic Groups.

$\mathrm{Pb}$ was detected in only 2 of the 35 samples, in miss lovely lip gloss and milanni (MB) beauty lipstick respectively. The $\mathrm{Pb}$ content of the lip gloss is below the threshold but that of lipstick is only above the standard of Germany and EU. Our result is in consonance with Sahu et al. (2014) where no $\mathrm{Pb}$ was detected in the 41 samples presented for analysis. However, in contrast, Liu et al. (2013), Orisakwe et al. (2016) and Sani et al. (2016) reported the presence of $\mathrm{Pb}$ in all the samples analyzed. Even low levels of $\mathrm{Pb}(<25 \mu \mathrm{g} / \mathrm{dl})$ over a period of years is known to cause reduced fertility, increase in risks of spontaneous abortion, reduced fetal growth and low birth weight (Bellinger, 2005).

\section{Conclusion}

Metal concentrations in cosmetics have been reported more than 50 years ago (Byers R.K and Lord E.E, 1943) but these updates have become inevitable in order to monitor production standards, encourage good manufacturing practice, and create awareness on the safety of these products to the consumers. Our result shows that $40 \%$ of all products marginally exceeded the EU standard for Cd while 74.28 $\%$ of $\mathrm{Ni}$ exceeded the acceptable daily intake threshold for adults. For Mn, $17.14 \%$ of the total products exceeded the acceptable daily intake threshold while only one product in lead exceeded the standard. In addition, the mean values indicates that $\mathrm{Mn}>\mathrm{Ni}>\mathrm{Cr}>\mathrm{Cd}>$ $\mathrm{Pb}$ in all the samples analyzed. Though the result shows a marginal amount beyond the standard for most of metals detected except $\mathrm{Mn}$ in which the margin was large, even low metal content are still risk factors considering the high doses of cosmetics consumed daily. Figure 1 compares in brief the concentration of metals in each group of cosmetic groups used.

\section{Acknowledgement}

The authors deeply appreciate effort of Dr Okibe Friday in ensuring timely release of result, Amadu Bello University zaria technologist for the quality analysis done and Dr Itodo for his technical assistance.

\section{References}

[1] Ackah M, J. Osei, A. K. Anim, N. Zakaria, E.S. Nyarko, E. T. Gyamfi, S. Enti-Brown, J.E.K. Hanson, N.O.Bentil and D. Tulasi (2015). Status of Some Metals Contained in Imported Nail Polish and Lipsticks on the Ghanian Market. Proceedings of the International Academy of Ecology and Environmental Sciences 5 (4):142-147.

[2] Agency for Toxic Substance and Disease Registry (2014). The Priority List of Hazardous Substances that will be the subject of Toxicological profile. http://www.atsdr.cdc.gov/spl (accessed on 20 July 2019).

[3] Agency for Toxic Substances and Disease Registry (2012). Toxicological profile for Chromium. Atlanta, GA: US Public Health Service.

[4] Ahmad A, M.H Sayed, S. Barua, M.H.Khan, M.H.Faruquee, A.Jalil, S.A.Hadi and H.K.Talukder (2001). Arsenal in drinking water and pregnancy outcome. Environmental Health Perspectives 109: (6) 29-97.https://doi.org/10.1289/ehp.01109629.

[5] Al-Bader A, Omu AE, and Dasti H (1999). Chronic Cadmium Toxicity to Sperm of Heavy Cigarette Smokers: Immunomodulation by Zinc. Archives of Andrology; 43 (3):135-140.https://doi.org/10.1080/014850199262643.

[6] Aldayel O, Hefne J, Alharbi and Al-jyan T (2018). Heavy metal concentrations in facial cosmetics. Natural product chemistry and Research 6: (1) $1-9$.

[7] ASEAN Guidelines on limits of cosmetics; ASEAN Cosmetic Scientific Body (ACSB) Meeting 2nd-3 ${ }^{\text {rd }}$ May 2017, Siem Reap, Cambodiaand endorsed at the $26^{\text {th }}$ ASEAN Cosmetic Committee (ACC) MEETING 4th-5thMay2017, Siem Reap, Cambodia. https://www.hsa.gov.sg/.../Cosmetic.../ASEAN\%20Guidelines\%20on\%20Limits\%20of.

[8] Bellinger CD (2008). Very low lead exposures and children's neurodevelopment. Therapeutics and Toxicology 20: 172177.https://doi.org/10.1097/MOP.0b013e3282f4f97b.

[9] Bellinger CD (2005). Terotogen Update: Lead and Pregnancy. Clinical and Molecular Teratology 73:409-420.https://doi.org/10.1002/bdra.20127.

[10] Campaign for Safe Cosmetics (2007). A poison kiss: the problem of lead in lipsticks. www.safecosmetics.org.

[11] Chan, E (2012) Health Canada Published Guidelines on Heavy Metal Impurities in Cosmetics. Sparkle Volume 63.

[12] Available online: http://www.intertek.co.th/uploadedFiles/Intertek/Divisions/Consumer_Goods/.

[13] Media/PDFs/Sparkles/2012/sparkle632.pdf (accessed on 26 July 2019).

[14] Chia SE, Xu B, Ong CN, Tsakok FM and Lee ST (1994). The effects of cadmium and cigarette smoking on human semen quality. International Journal of fertility and menopausal studies. 9: 292-298.

[15] Dickson H, Parker L (1994). Do alcohol and lead change the sex ratio? Journal of Theoretical Biology 169: 313315.https://doi.org/10.1006/jtbi.1994.1152.

[16] Dykeman R, Aguila-Madrid G, Smith T (2002). Lead exposure in Mexico Radiator Repair Workers. American Journal of Industrial Medicine 41: 179-187.https://doi.org/10.1002/ajim.10044. 
[17] Eibensteine L, Delcarsanz A, Frumkin H, Lead exposure and semen quality among traffic police in Arequipa, Peru. International Journal of Occupational and Environmental Health 11: (1) 166-170.https://doi.org/10.1179/oeh.2005.11.2.161.

[18] Encyclopaedia Encarta (2009), DVD. Redmond, WA; Microsoft Corporation 2008.

[19] Fagher U, Laudanski T, Schutz A, Sipowicz M, Akerlund M (1993). The relationship between cadmium and lead burdens on preterm labour. International Journal of Gynaecology and Obstetrics 40: 109-114.https://doi.org/10.1016/0020-7292(93)90368-7.

[20] Henson MC, Chedrese PJ (2004). Endocrine disruption by cadmium, a common environmental toxicant with paradoxical effects on reproduction. Experimental Biology and Medicine 229 (5): 383-392.https://doi.org/10.1177/153537020422900506.

[21] Hostynek J (2003). Factors determining percutaneous metal absorption. Food Chemistry and Toxicology 41: 327345.https://doi.org/10.1016/S0278-6915(02)00257-0.

[22] International Agency for Research on Cancer (IARC, 2012). Arsenic, metals, fibres and dusts. IARC monograph on the Evaluation of Carcinogenic Risks to Humans 100 (PtB) :1-441.

[23] Itai Y, Fujino T, Ueno K and Motomatsu Y (2004). An Epidemiological Study of the Incidence of Abnormal Pregnancy in Areas Infected Heavily with Contaminated Methylmercury. Environmental Science 11 (2): 83-97.

[24] James WH (2006). Offspring sex ratios at birth as markers of potential endocrine disruption. Environmental Resources 100: 77-85. https://doi.org/10.1016/j.envres.2005.03.001.

[25] Jana K, Jana S, Samanta PK (2006). Effects of Chronic exposure to sodium arsenite on hypothalamo-pituitory-testicular activities in adult rats: possible an estrogen mode of action. Reproductive Biology and Endocrinology 4: 9.https://doi.org/10.1186/1477-7827-4-9.

[26] Joint FAO/WHO Expert Committee on Food Additives. Meeting. (57th: Rome, Italy, 2001). Safety Evaluation of Certain Food Additives and Contaminants/Prepared by the Fifty-Seventh Meeting of the Joint FAO/WHO Expert Committee on Food Additives (JECFA); World Health Organization: Geneva, Switzerland, 2002

[27] Available online: https://www.who.int/foodsafety/areas_work/chemical-risks/jecfa/en/ (accessed on 26 July 2019).

[28] Jolibois LS, Shi W, George WJ, Henson MC, Anderson M.B (1999). Cadmium accumulation and effects on progesterone released by cultured human trophoblast cells. Reproductive Toxicology 13 (3): 215-21.https://doi.org/10.1016/S0890-6238(99)00009-X.

[29] Jolibois LS, Burow ME, Swan KF, George WJ, Anderson MB, Henson MC (1999). Effects of cadmium on cell viability, trophoblastic development and expression of low density lipoprotein receptor transcripts in cultured human placental cells. Reproductive Toxicology, 13 (6):473-80. https://doi.org/10.1016/S0890-6238(99)00041-6.

[30] Larese FF, Boeniger M, Maina G, Spinelli P, and Damian A (2006). Skin absorption of inorganic lead (PbO) and the effects of skin cleansers. Journal of Occupational and Environmental Medicine 48: 692.https://doi.org/10.1097/01.jom.0000214474.61563.1c

[31] Larese F, Fiorito A, Adami G (1999). Skin absorption in vitro of glycol ethers. International Archives of Occupational and Environmental Health, 72 (7): 480-484.https://doi.org/10.1007/s004200050402.

[32] Liu S, Hammond SK, Rojas-cheathan A (2013). Concentrations and Potential Health Risks of Metals in Lip products. Environmental Health Perspectives. 121 (6) 705-710.https://doi.org/10.1289/ehp.1205518

[33] Livingstone C, Collison M (2002). Sex steroids and insulin resistance. Clinical science, London 102: 151-166.https://doi.org/10.1042/cs1020151.

[34] Mendola P, Messer LC, and Rappazzo K (2008). Science Linking Environmental Contaminant Exposure with Fertility and Reproductive Health Impacts in Adult Female. Fertility and Sterility 89: (1) 81-93.https://doi.org/10.1016/j.fertnstert.2007.12.036.

[35] Miranda M L, Kim D, Galeano M A, Paul C J, Hull A P (2007) The relationship between early childhood blood lead levels and performance on end-of-grade tests. Environmental Health Perspective 115: 1242-1247.https://doi.org/10.1289/ehp.9994.

[36] Nasirudeen MB and Amaechi AU (2015). Spectrophotometric Determination of Heavy Metals in Cosmetics Sourced from Kaduna Metropolis, Nigeria. Science World Journal 10 (3) 1-5.

[37] Nishijo M, Nakagawa H, Honda R, Tanabe K, Saito S, Teranishi H, Tawara K (2002). Effects of maternal exposure to cadmium on pregnancy outcome and breast milk. Occupational and Environmental Medicine 59: 394-397.https://doi.org/10.1136/oem.59.6.394.

[38] Official Journal of the European Union. Regulation (EC) No 1881/2006 of 19 December 2006 on Setting Maximum Levels for Certain Contaminants in Foodstuffs. 2006. Available online: https:/eur-lex.europa.eu/legal-content/EN/TXT/PDF/?uri=CELEX:32006R1881\&from=EN (accessed on 26 July 2019).

[39] Orisakwe O E and Otaraku JO (2013). Metal concentrations in cosmetics commonly used in Nigeria. The scientific world Journal. Volume 2013, Article ID 959637, 7 pages.https://doi.org/10.1155/2013/959637.

[40] Rowland AS, Baird DD, Weinberg CR (1994). The Effects of Occupational Exposure to Mercury Vapour on Fertility of Female Dental Assistant. Occupational and Environmental Medicine 51: 28-34.https://doi.org/10.1136/oem.51.1.28.

[41] Sahu R, Saxena P, Johnson S (2014). "Heavy Metals in cosmetic. Centre for Science and Environment". 1:1-28.

[42] Sainic EL, Jolanki R, Hakala E and Kanerva L (2001). Metals and Arsenic in eye shadows. Contact Dermatitis 42 (1): 510.https://doi.org/10.1034/j.1600-0536.2000.042001005.x.

[43] Sani A, Maryam BG, Abubakar FA (2016). Determination of Some Heavy Metals in Selected Cosmetic Products sold in Kano Metropolis, Nigeria. Toxicology Reports 1:1-9.https://doi.org/10.1016/j.toxrep.2016.11.001.

[44] Saxena D K, Singh C, Murthy RC (1994). Blood and placental lead levels in an Indian City: A preliminary report. Archives of Environmental Health, 49 (2): 106-110.https://doi.org/10.1080/00039896.1994.9937462.

[45] Selevan SG, Rice DC, Hogan K A, Euling SY (2003). Blood lead concentration and delayed puberty in girls. North England Journal of Medicine 348 (15) 27-36.https://doi.org/10.1056/NEJMoa020880.

[46] Shaltout A, Yaish SA, Fernando N (1981). Lead encephalopathy in infants in Kuwait: A study of 20 infants with particular reference to clinical presentation and source of lead poisoning. Annual tropical Pediatric 1: 209-215. https://doi.org/10.1080/02724936.1981.11748090.

[47] Talisman S, Cvitkovic P, Jurasovic J, (2000). Semen quality and reproductive endocrine function in relation to biomarkers of lead, cadmium, zinc and copper in man (2000). Environmental Health Perspective 108: 45-50.https://doi.org/10.1289/ehp.0010845.

[48] Tang N, and Zhu ZQ (2003). Adverse reproductive effects in female workers of lead battery plant. International Journal of Occupational Medicine and Environmental Health 16 (3) 59-61.

[49] Tseng GH (2005). Blackfoot disease and arsenic: a never ending story. Journal of Environmental Science and Health 23 5574.https://doi.org/10.1081/GNC-200051860.

[50] Ullah Hussain, Shamsa Noreen, Fozia, Ali Rehman, Amir Waseem, Shumaila Zubair, Muhammad Adnan, Ijaz Ahmad (2017). Arabian Journal of Chemistry 10: 10-18.https://doi.org/10.1016/j.arabjc.2013.09.021.

[51] U.S. Food and Drug Administration. FDA's testing of Cosmetics for Arsenic, Cadmium, Chromium, Cobalt, Lead, Mercury, and Nickel Content. 2018. Available online: https://www.fda.gov/Cosmetics/ProductsIngredients/PotentialContaminants/ucm452836.htm (accessed on 26 July 2019.

[52] Waalkes MP, Keefer LK, Diwan BA (2000). Induction to proliferation lesions of the uterus, testis and liver in Swiss mice given repeated injections of sodium arsenate: possible mode of action. Toxicology and Applied Pharmacology 166: 24-35.https://doi.org/10.1006/taap.2000.8963.

[53] Wang CL, Chuan HY, Ho CK, Yang CY, Tsai J.L, Wu TS and Wu TN (2002). The relationship between blood lead concentration and learning achievement among primary school children in Taiwan. Environmental Resources 89 (1): 12-18.https://doi.org/10.1006/enrs.2002.4342.

[54] Whitehouse L, Germany Reduces Heavy Metal Limits in Cosmetics. 2017. Available online: https://www.cosmeticsdesigneurope.com/Article/2017/07/25/Germany-reduces-heavy-metal-limits-in-cosmetics (accessed on 25 July 2019.

[55] Wu T, Buck GM, Mendola P (2003). Blood lead levels and sexual maturation in US girls. The third National Health and Nutrition Examination Survey. Environmental Health Perspective 111 (7) 37-41.

[56] Yang CY, Sung F (2006). Low blood lead concentration in association with infertility in women. Environmental Resources 101 (38) 1-6.

[57] Zhai H, Maibach H, (2001). Effects of skin occlusion on percutaneous absorption. An overview: skin pharmacology and applied skin physiology 14: 1-10.https://doi.org/10.1159/000056328. 